\title{
THE EFFECT OF ZOOM MEETING ON E-LEARNING IN STUDENTS' SPEAKING SKILL
}

\author{
$1^{\text {st }}$ Fitriani Guci \\ English Language Teaching Department \\ Universitas Panca sakti Bekasi \\ f.guci18@gmail.com
}

\author{
$2^{\text {nd }}$ Leroy Holman Siahaan \\ English Language Teaching Department \\ Universitas Panca Sakti Bekasi \\ leroyholmansiahaan@gmail.com
}

\begin{abstract}
This research aims to find out the effect of zoom meeting on e-learning in student speaking skill at ninth grade of SMPN 35 Bekasi. The use of zoom meetings supports the learning process in the covid-19 pandemic. This research was conducted in July 2021. The analysis used in quantitative research is experimental design. This research sample is 40 students in grade ninth with divided into two groups, namely a control group with a total of 20 students and an experiment group with a total of 20 students. Data collection is carried out with a test technique system to get the results of students' speaking skills. Statistical test using SPSS 22. The results showed that there was a difference between the control group and the experiment group. This can be proven by; 1 . Instrument test results with a reliability level of 0.800 which means that the results are valid. 2. 2. the test result $t$ is a significance score (2-tailed) from the test result of $0.00<0.05$ so that a sig score of 0.00 is seen to show the effect of using zoom meetings in speech ability in SMPN 35 Bekasi.
\end{abstract}

Keywords: Effect; zoom meeting; speaking skill

\section{INTRODUCTION}

English is an international language that is used as a language of communication between all nations and countries throughout the world. The ability to speak English is one of the abilities that is very important for students because English has become a universal language used in the world of technology, education, politics, commerce, and is the commonly used communication tool by the world. In English learning there are four skills, namely speaking, reading, listening, writing. This research focuses on speaking skills. Speaking has the purpose of conveying verbally and in reciprocal communication.

Bahadorfar (2015: 9) speaking skills can be categorized as good speaking skill when the listener can understand the words produced by the speaker. Irawati (2014) speaking as an activity to produce sayings in the form the words and sentences orally to communicate with other. Speaking is the process of expressing opinions in the mind. In addition, speech skills are the use orally with good vocabulary, polite and express the content of our thoughts through feelings and ideas for communication between people.
Since the last two years to be precise in September in a country in Asia, namely Wuhan (China). There has been outbreak of the virus namely corona or covid-19 to be precise in the city of Wuhan. In China it implements the closure of borders and all sectors like economic, education and transportation. The pandemic has spread around the world including Indonesia, to limit the spread of the covid-19 virus in a lockdown. lockdown is close all areas both outside and to a region and restrict human movement including schools, transport, the economy.

In the past one year, Indonesia experienced pandemic Covid-19. President Joko Widodo announced the first two positive cases of covid-19 on March 2, 2020. On March 31, 2020, there was an increase in positive cases in Indonesia, President Joko Widodo announced the status of public health emergencies. The central government imposes large-scale social restrictions (PSBB) instead of regional quarantine or lockdown (BBC, 2020). The spread of this virus has caused many losses in Indonesia, especially in the economic and transportation sectors and education sectors. Covid-19 has also an impact on the world of education 
institutions are temporarily closed, teacher and students must be professional in work and study. The learning process should be developed in this situation. Various innovations have been made to develop and advance the quality of student. The many innovations carried out in the world of education. Including the use of information communication technology to simplify the learning process or what we know as elearning is currently very much needed.

One of the government's policies is to eliminate all learning activities that are then converted into online or e-learning. The elearning education system can be implemented appropriately in schools. Teacher assignments assist students in solving learning problems that cannot be solved in the classroom and are poorly understood by students with e-learning systems can be easier and faster in the learning process. It is currently in the digital era starting from the finance and transportation section. The process of teaching and learning activities in schools will follow the renewal where we have entered the digital era. During the covid-19 pandemic, the education system in Indonesia supported the renewal of education with a system of teaching and learning activities in schools using e-learning-based technology.

According Kamarga (in simanihuruk, et. al., 2019) e-learning is regarding the meaning of learning namely, teaching materials used during learning activities are obtained by accessing them through computer electronic devices. While Linde (in Simanihuruk, et al., 2019) e-learning is formal and informal learning using electronic media such as the internet, $\mathrm{CD}$ ROM, video cassette, DVD, TV, mobile phone, PDA etc. e-learning method using internet-based technology the learning proses students and teachers can communicate well using technology. Students and teachers who follow e-learning programs can save time and effort. Flexible time and activities are only from home. Facilitate other activities.

The selection of learning media in the covid-19 pandemic of internet-based technology must be considered appropriately because otherwise it will be bad for students. Advances in technology now allow students to learn from home entirely online, with online learning systems that can be through videos and files. One of the distance learning media that can be used is video. Video can replace face-to-face learning before the covid-19 pandemic. After the occurrence of the covid-19 virus online learning through video can be replaced virtually through applications connected to the internet. Elearning media to help with the process such as zoom application, google meet, google classroom and WhatsApp but many school choose to use zoom meeting in learning because the application provides a face-toface online system.

According Korman (2020) zoom is video conferencing application that you can utilize it to communicate remotely with others-either video or audio-only, or both while holding live chats-and it allows you record those sessions for viewing later zoom can only be accessed via internet using computer and mobile phone. Haqien \& Rahman (2020) state that Zoom meeting application is a video-based learning. zoom meeting is can only be accessed via internet using a tablet, computer, or other mobile phone. The zoom application can be downloaded on the play store and app store. There are two types of zoom meeting free and paid.

In addition, teachers can also build their knowledge and are able to provide interesting and effective learning. The use of zoom applications is good for students and teachers because by using zoom teaching and learning activities do not see distance and time. Zoom meetings can be used through a laptop or computer or smartphone. Zoom meeting as a medium of long-distance communication by combining video conferencing, chat, online meetings. This zoom application has many benefits in the world of Education. One of the benefits of Zoom meetings can be used for presentations, discussions, and webinars.

According Vadakedath (2020) Conventional method in traditional 
classroom teaching, although we deal with process of human disease, what is very important for teacher is to know how much the learners can understand it. Conventional learning is a teacher-focused learning. this method students tend to get bored. This model is usually used by teachers such as providing material or teacher centered.

In pandemic we are using zoom meeting application but zoom many obstacles in using this application such as, student tends to bore with learning, lack of communication, lazy. When learning English, a teacher provides a topic to discuss in English, but students speak Indonesia, which makes them not use English in lessons, but when they are not online the use English during class hour.

This research is to find out if there is a significant effect on the learning process with zoom meeting. It seeks to answer the following research questions: (1) is the use of zoom media effective in improving students speaking skills in English? (2) is there any interaction using zoom media and conventional in speaking skill? (3) which one is the better teacher using zoom or conventional?

The results of previous research conducted by Marsiding (2021) can be said that the results obtained by this study show that the use of zoom meeting application to study in elementary school, especially at SDN 117 Leppangeng Bone is still categorized as "less effective". The obstacle factors for distance learning are less effective through the zoom meeting application, namely are still some students who do not have smartphone and laptop facilities that can access the application, there are still parents and teachers have not mastered how to operate the zoom meeting application, low skin signal in some areas where students and teachers live are also a factor obstacle to the still ineffective use of zoom application for the student.

Based on previous research zoom is very ineffective in the learning process. The researchers wanted to find out the effect of zoom meetings on e-learning learning in students' speaking skills that are influential or not in the process of learning English.

\section{METHOD}

The researchers used quantitative method for this research. The analysis used in quantitative research is experimental design. Two groups of control and experiment were used. The experimental group was the group that was treated with zoom while the control group was not given treatment. The data obtained from the student's pre-test result will be compared to the experimental class which is the result of the post-test.

This research was conducted at SMPN 35 Bekasi. This research was conducted from 26 July to 30 July 2021 . The population in this research was grade 9 at SMPN 35 Bekasi which consisted of 8 classes. The sample used is class 9 (3) which is as many as 40 students.

The research method to collect valid data by using a test. According Mulyatiningsih (2014), test is a method of data collection in research that serves to measure a person's ability. Test is divided into two, namely pre-test and post-test. Pretest are conducted before being treated to find out how far the impact of speaking students in this pandemic. Post-test was conducted to determine the influence of speaking students after being treated using zoom meeting about hope and wish.

This research instrument used is a speaking test. This test aims to measure students' speech ability. this test is to obtain data on learning outcomes in experimental classes and control classes. This technique is carried out twice, namely pre-test and posttest in this test. students are asked to notify hope and wish. The material is hope and wish is conversations. The data analysis techniques used in this research are as:

\section{a. Instrument test}

The test instrument consists of two tests, namely validity and reliability. validity is a level that indicates to abstention or valid a measuring instrument. Whiston (2012) defined validity as obtaining data that is appropriate for the intended use of measuring instrument. Reliability is a 
consistent measurement of tests. Repeated tests of fixed results.

b. Reliability kappa Cohen reliability test. According to Fliess (1981) reliability cappa Cohen is a test used to see the level of interrater. To find the reliability of Cohen kappa used the formula.

Reliability categories between raters as: Kappa $<0,4$ bad.

Kappa 0,4-0,60 pass.

Kappa 0,60-0,75 good.

Kappa $>0,75$ excellent.

c. Paired t-test.

Test is used to compare true or incorrect in this t-test using post-test result.

Aspects of speaking assessment consist of content, organization, language use, vocabulary, mechanics. This valuation consists of six levels seen in table 1 .

\begin{tabular}{cc} 
Table 1 & \\
\hline Score & Classification \\
\hline 6 & excellent \\
\hline 5 & Very good \\
\hline 4 & Good \\
\hline 3 & Pass \\
\hline 2 & Weak \\
\hline 1 & Very poor \\
\hline
\end{tabular}

\section{RESULTS AND DISCUSSION}

To find out the effect of zoom on student's speaking skill by using the post-test result of grade 93 students as many as 20 people at SMPN35 Bekasi. The data that has been collected is quantitative data in the form of speak is for the highest is 6 (excellent) and the lowest score is 1 (very poor). This test in the form of a conversation about expectations with the use of zoom meetings in experimental groups. After conducting the test, researchers obtained the post-test results using zoom meeting. The highest score is five (very good) and the lowest is 2 (weak). The result post-test can be seen in table 2.
Table 2 The Result Post-test

\begin{tabular}{cccccc}
\hline No absent & Content & Vocabulary & Organization & langugee use & Mechanics \\
\hline 21 & 4 & 5 & 4 & 4 & 4 \\
\hline 22 & 4 & 5 & 3 & 5 & 5 \\
\hline 23 & 2 & 3 & 2 & 5 & 3 \\
\hline 24 & 4 & 5 & 4 & 3 & 4 \\
\hline 25 & 5 & 5 & 5 & 3 & 5 \\
\hline 26 & 4 & 5 & 5 & 4 & 3 \\
\hline 27 & 3 & 3 & 2 & 4 & 4 \\
\hline 28 & 3 & 3 & 3 & 4 & 3 \\
\hline 29 & 4 & 5 & 5 & 3 & 5 \\
\hline 30 & 4 & 5 & 5 & 4 & 4 \\
\hline 31 & 4 & 5 & 5 & 4 & 4 \\
\hline 32 & 4 & 3 & 4 & 5 & 2 \\
\hline 33 & 4 & 3 & 5 & 3 & 2 \\
\hline 34 & 3 & 3 & 2 & 2 & 2 \\
\hline 35 & 4 & 2 & 5 & 3 & 4 \\
\hline 36 & 5 & 4 & 5 & 4 & 5 \\
\hline 37 & 5 & 3 & 4 & 4 & 4 \\
\hline 38 & 5 & 4 & 5 & 5 & 4 \\
\hline 39 & 3 & 3 & 3 & 3 & 4 \\
\hline 40 & 3 & 4 & 3 & 5 & 4 \\
\hline & & & & &
\end{tabular}

The researchers tested the results of statistic using SPSS 22. Tests conducted are instrument test, Kappa Cohen reliability test, paired $\mathrm{t}$-test.

\section{Instrument Test}

Validity test using bivariate correlation person. 
Table 3 Result Validity Test

\begin{tabular}{|c|c|c|}
\hline Variable & Correlation & Description \\
\hline Content & 0,778 & Valid \\
\hline Vocabulary & 0,760 & Valid \\
\hline Organization & 0,737 & Valid \\
\hline Language use & 0,676 & Valid \\
\hline mechanics & 0,755 & Valid \\
\hline
\end{tabular}

Based on the validity test results, all items are declared valid because $r$ items the $>r$ table where table $\mathrm{N}-2$ is df $18=0.468$. reliability test using Cronbach alpha tests are said to be reliable or valid if greater than 0,70. Based on the result of the reliability test Cronbach alpha value $0,790>0,70$ so that it can be concluded the test speaks using a reliable or valid zoom meeting. Test result can be seen in the table 5 .

Table 5. Reliability Test

\begin{tabular}{|c|c|}
\hline Cronbach's alpha & N of items \\
\hline .790 & 5 \\
\hline
\end{tabular}

\section{Uji reliability kappa Cohen}

Kappa Cohens reliability test in this study was conducted by calculating inter-rater in assessing speech factor in e- learning, learning using zoom meeting.

Researchers used kappa Cohen to find out the difference between teacher one and teacher two.

Table 6 Reliability Cappa Cohen

\begin{tabular}{|c|c|c|c|c|}
\hline & value & Asmp.std. error & Approx.tb & Approx. Sig. \\
\hline $\begin{array}{ll}\text { Measure } & \text { of } \\
\text { agreement } & \\
\text { kappa } & \end{array}$ & .800 & 1.31 & .3651 & 0,000 \\
\hline $\mathrm{N}$ of valid cases & 20 & & & \\
\hline
\end{tabular}

Kappa Cohen's reliability test is conducted by calculating the inter-rater to see the opinions between two experts by assessing the success factor of using zoom in students' speech skills. Kappa Cohen test using SPSS
22

From the result in table above obtained the coefficient value of kappa Cohen significance of 0.800. means between teacher 1 dan teacher 2 against test scores in students is 
very strong. The significance value can be seen in the forecast column 0.00 because the significance level used by $5 \%$ which is 0.00 $>0.05$ agreement between teacher 1 and teacher 2 on the effect of zoom meeting with student speaking skill. the result has a relationship between teachers one dan teacher two. Based on table 7 the reliability coefficient between raters of 0.800 can be interpreted in very satisfactory categories because the coefficient value of alpha > 0.75 .

Paired sample t test

Paired $t$ test Sample $t$ test to find out the average difference, so that it is responded whether zoom has an effect in students speaking skills in this pandemic. From on table 5, the test result pairs the paired t test using SPSS 22. Value of significance test $t$ sig test. (2-tail) in the table above. The significance score (2-tailed) of this study was $0.000<0.05$ so a sig score of 0.000 was seen to indicate that the influence of zoom meeting students speaking skill in grade 93.

The results of the paired sample t test can be seen on table 7 .

Table 7 Paired Sample t Test

\begin{tabular}{|c|c|c|c|c|c|c|c|}
\hline & \multicolumn{4}{|c|}{ Paired difference } & \multirow[t]{3}{*}{$\mathrm{t}$} & \multirow[t]{3}{*}{ df } & \multirow{3}{*}{$\begin{array}{l}\text { Sig. (2- } \\
\text { tailed) }\end{array}$} \\
\hline & \multirow[t]{2}{*}{ mean } & \multirow[t]{2}{*}{$\begin{array}{c}\text { Std } \\
\text { Division }\end{array}$} & \multirow[t]{2}{*}{$\begin{array}{l}\text { Std. } \\
\text { Error } \\
\text { mean }\end{array}$} & $\begin{array}{l}95 \% \text { confidence } \\
\text { interval of the } \\
\text { difference }\end{array}$ & & & \\
\hline & & & & Lower upper & & & \\
\hline & 5.0500 & 2.0384 & .4558 & $4.0959 \quad 6.0958$ & 11.079 & 19 & \\
\hline $\begin{array}{c}\text { PRE } \\
\text { - }\end{array}$ & 0 & 5 & 1 & 8 & & & 0,000 \\
\hline $\begin{array}{c}\text { POS } \\
\text { T }\end{array}$ & & & & & & & \\
\hline
\end{tabular}


Related to the results of the study, discussions to strengthen the results of research. Firs, the results showed that test scores had a significant influence in understanding the speaking skills of students who used zoom meeting media in the elearning process during this pandemic. This can be seen in the validity and validity test result. Second, mastery of student's speaking skills during the pandemic does not reduce student's interest in communicating with English. Third, first and second grades decides that grade 93 students who used zoom media were very effective, whereas for face to-face assessment 1 students rarely spoke English. Fourth, the use of zoom meetings runs effectively. So, the researchers' goal was achieved.

\section{CONCLUSION}

The researchers obtained data on the use zoom meeting on speaking skills in the process of e-learning. it can be concluded that the application of zoom meeting has an influence and significance on the ability to speak students in grade 93. It can be proven that the average value of the experiment class is greater that the value of the control classes the magnitude of the influence of zoom meeting shown on the test instrument results. Furthermore, with the test obtained a test significance score of $0.000>0.05$ which looks influential. The results support several previous studies on the use of zoom meetings. Researchers suggest they are:

a. For students, zoom meeting-based learning can assist students in improving their English skills during the pandemic.

b. For teacher of English subjects, can maximize the learning process by applying zoom meetings because to improve the speaking skill of teachers and students.

c. for schools, schools encourage the implementation of media zoom meetings through training and facilitate the internet quota of teachers and students.

Media zoom meeting can be used as a teaching method like face-to-face and effective.

\section{REFERENCES}

Bahadorfar, M. O. (2015). Technology in teaching speaking skill. acne international journal of multidiscpilinary, 34-50.

BBC, N. (2020, APRIL 1). BBC News Indonesia. Retrieved from: Https://www.bbc.com/indonesia/indonesia $-52109439$

Fliess, J. L. (1981). Stastical methods for rates and proportions. New York: Willeyinterscience.

Haqien, D., \& Rahman, A. A. (2020). Pemanfaatan Zoom Meeting untuk Proses Pembelajaran Pada Masa Pandemic Covid-19. jurnal SAP, 5, 51-56.

Irawati. (2014). Imrproving Students Speaking Ability Through Communicate Language Games. Magistra, 25-36.

Korman, C. (2020). Zoom for teacher 2020 : a Complete Guide to Learn Zoom Cloud Meetings for Video, Webinars, Live Stream Conference, and Classroom Management. Independently publshed.

Mulyatiningsih, E. (2014). Metode penelitian Terapan Bidang pendidikan. Bandung: Cv. Alfabeta.

Simanihuruk, 1. et. al. (2019). E-learning Implementasi, Strategi \& Inovasinya. Yasasan kita menulis.

Vadakedath, E. A. (2018). Conventional Methods of Teaching. IGI PUBLISHER.

Whiston, S. C. (2012). Principles and Applications of Assesment in Counseling. USA: Cengage learning.

Marsiding, Z. (2020). Efektifitas Penggunaan Media Zoom Terhadap Pembelajaran pada Masa Pandemic Covid-19. uit.e-journal.id, 2, 33-39. 